マレック病扮よび七面鳥ヘルペスウイルスの構造とその起病性

岡田幸助*

マレック病（MD）はニワトリの伝染性腫瘍性疾患 で, 臨床的には麻痺を特徵とし, 損耗率も高い。七面鳥 ヘルペスウイルス（HVT）はMDのワクチンとして, 10年程前から広く応用され，MDの予防に輝かしい成果 を扮さめた、筆者は過去 10 数年間, 北海道大学比較病 理学教室に拈いて藤本 胖教授御指導のもとで, 主に病 理形態学の立場から, 特飞電子顕微鏡(電顕)を用いて 本病の本態解明に努力してきた。本稿ではMDの原因ウ イルスがぞのような形態をしているか，それはどのよう にして增殖するのか，ニワトリの体の中に入ってどのよ うな病変を作るのか，そしてどのようにして腫瑄が形成 されるのか的をしぼって, 紙数にも限りがあるので, 自家所見を中心筆者の理解するところ解説してみた い.MDぶニワトリ白血病群から分離独立されたいきさ つについては総説40)を, MDの病理形態学については藤 本の総説10,11を特読みいただければ幸である。

\section{1. マレック病ウイルス（MDV) ならびに HVTの形態発生}

\section{1) 成熟粒子の形態}

MDはへルペスウイルスB群に属するMDVによって 起こることが明らかにさ机ている7゙.いっぽう, 一見健康 な七面鳥から分離さ机た HV T ${ }^{25,64)}$ はMDV 之共通抗原 を持ちニワトリに起病性がないために，MDのワクチン として利用されている ${ }^{50)}$. 筆者ら ${ }^{46)}$ は両ウイルスの超微 形態とその形態発生について検討した。雨ウイルス基

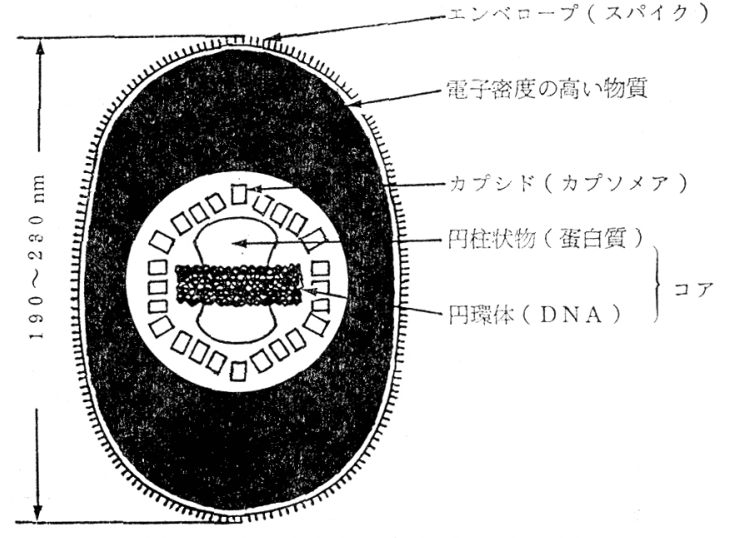

圀1 MDV大型成熟粒子の模型図

* 岩手大学農学部（盛岡市上田3-18-8）

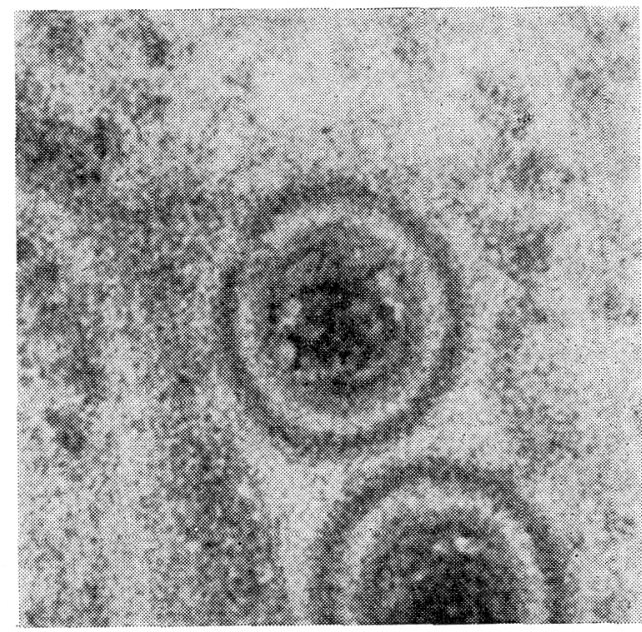

写真 1 核膜腔内に拈ける小型のエンベロープを 持ったMDV粒子 ${ }^{47)}$

本的には同一形態を示し，エンベロープを持つ粒子は以 下の 2 種類存在した。一つは直径 190〜230 nm で細胞 質小胞体内, 細胞質封入体内または細胞外汇存在した (図 1). 他の一つは直径 $140 \sim 170 \mathrm{~nm}$ で核膜腔に存在 した(写真 1). 両者の中心に㥀径 $100 \mathrm{~nm}$ 正 20 面体 のカプシドが存在し，そのカプシドは 162 個のカプソメ アからなっていた. 岂らにカプシドの中心灶コアが存
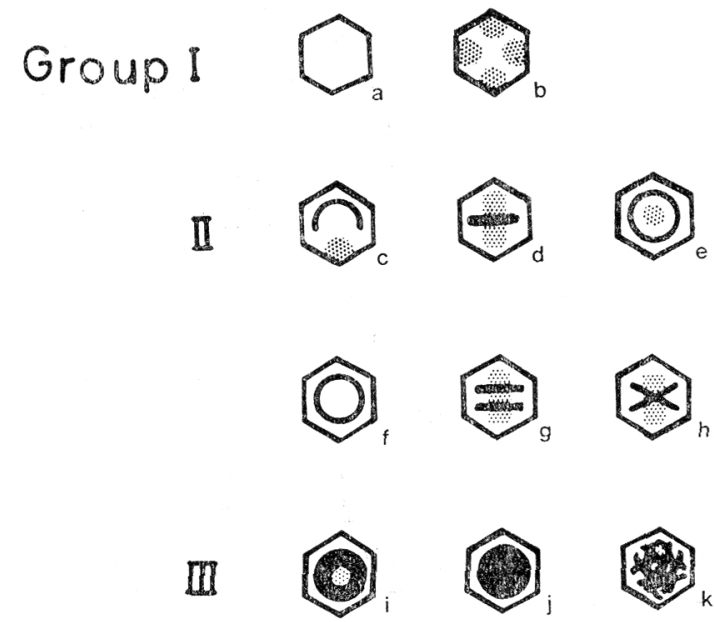

図 2 MDV小よびHVTのさまざまなコアの形 態によるカプシドの分類 ${ }^{47)}$

日獣会誌 $34 \quad 463 \sim 471 \quad$ (1981) 


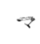

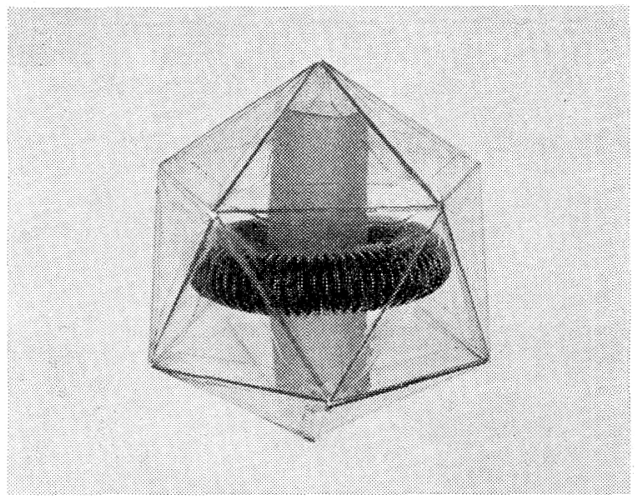

写真 2 MDVおよびHVTのコアの立体模型47)

在した.このコアについては後で詳しく述べる. 大型成 熟粒子はカプシドとェンベロープの間に電子密度の高い 物質を多量に含み，エンベロープの表面にスパイク状の 突起を持っていた。

\section{2） 傾斜装置によるコアの立体構造の検討}

感染細胞の核内には直径 $30 \mathrm{~nm}$ の小型核内粒子 (small nuclear particle) とカプシドとコアからなる未熟粒子 が多数認められた 、筆者が特に興味を持ったのは，こ れら末熟粒子のコアが図2のよらにさまざまな形態を示 すことであっだ7. 第一印象として，これらのコアの多 形性はそれぞれのウイルスの成熟過程を示しているので はないかと考壳た、そこでまず，これらのウイルスコア を電顕の試料傾斜装置を用いて角度の異なる写真を 2 枚 とり，ステレオスコープの下で立体視する方法により， その立体像を検討し，1972 年に発表しだ6)。当時， peculiar shaped core（奇妙な形のコア）と呼えだ2個の 直交するドーナッ状リング（以下，円環体と呼ぶ）がMD Vのコアの立体モデルであると考光た、いっぽう，われ われとほぼ同時にアメリカの FURLONG ら ら $^{18)}$ が Herpes simplex 1 型で，そのコアは写真 2 そような 1 個の円環 体とそれを貫通する 1 個の電子密度の低い円柱状物から なると報告し，後 NAZERIAN ${ }^{31)}$ によりMDVでる， そのような同様形態のコアのモデルが発表された。われ われは当時開発されたばかりの傾斜装置による観察を行 なって怙りかなりの自信があったが，当時は 2 万位に しか傾斜されていなかった ${ }^{46,49}$. 三次元構造の確証には 4 万位に傾斜させることが必要である。サンプルを 4 万 位に傾斜させて観察した結果，写真 3 のごとく円柱と円 環体からなるコアが確認されだ7)。

\section{3）コンピューターによるコア断面像の再生}

次にコンピューターによる立体構造の再構築を試み $た^{1,2,49)}$. その原理は近年医学の分野で脳溢血等の際, 出 血部位を的確に診断し，大いに威力を発揮しているコン ピュータートモグラフィー（CTスキャン）とよく似て いる.これは身体のいろいろな角度からX線像を撮影

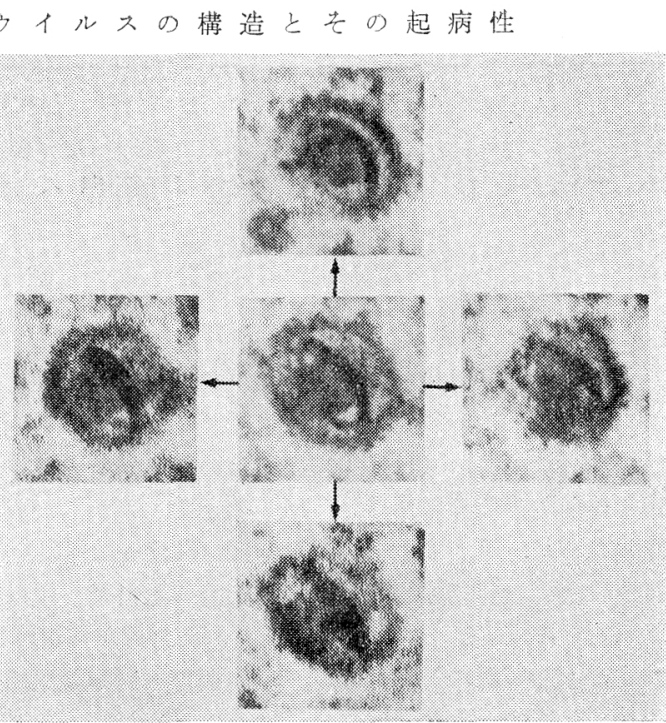

写真 34 方位に傾斜させることにより生じた HVTコア投影像の変化 ${ }^{47}$ )

し，それをコンピューターで処理し，身体の断面像をブ ラウン管上に表示しょうというものである。電顕像も電 子線を線源とした投影像であり，それから断面像を再生 することは理論上可能ではあるが，電顕の試料の傾斜角

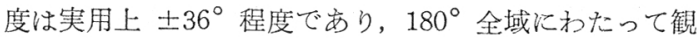
察ができない，そこで，逐次近似法1または maximum entropy 法 ${ }^{2}$ といら計算方法を用いて処理した. 検索方法 としてはます゚サンプルを傾斜させることにより，-36 $\sim+36^{\circ}$ まで $3^{\circ}$ 間隔で計 25 枚の写真を撮影し, 検索 したい部分についてデンシトメーターでフィルム上の濃 度を測定した．次に大型計算機により $62 \times 62$ の画素か らなる断面像を計算し， Flying Spot Scaner ${ }^{28)}$ のブラウ ン管上に断面像を再生させた. 写真 4 はH T 感染細胞 核内の未熟粒子の中央部の断面像をコンピューターで再 生させたもので，図３坆その模型図である。傾斜角度に 制限があるため再生像の上预よび下の部分の再生が不十 分であるが，中心より円柱状物，円環体扣よびカプソメ アからなるカプシドが再生され，写真 2 のモデルが確証 された。

\section{4) コアの発育過程}

以上より全てのカプシドは電子密度の高い円環体ない 乙带の有䁫により3群に分けられるように思われた（図 $2)^{472}$. 第 1 群仙円環体を欠くもので, 全カプシドの $33 \%$ 占めた。第 2 群は 1 個または 2 個の円㯰体を持つ もので 37\% であった。 これらのコアはいずれも円環体 と円柱からなるコアの切片の切れ方と見る方向によるも のと思われた，例えば図 2 のと e は同じものを横と上 から見たものである。ささらにg，hも上から見ると $\mathrm{e}$ も あろう、c 泻写真 2 のらなコアが斜断されたものであ る。核内の未熟粒子涌常第 1 群または第 2 群に属し 


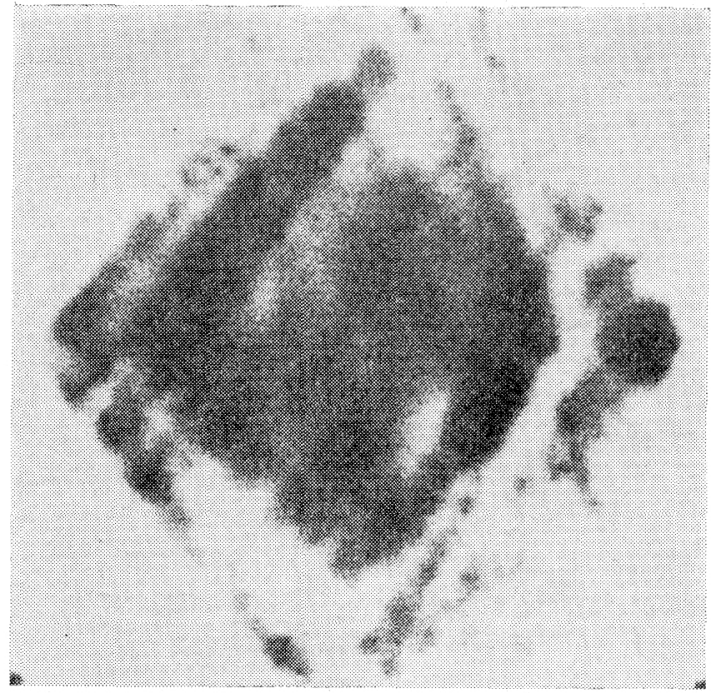

写真 4 コンピューターで再生させたHVT カプシドの断面像 ${ }^{1}$

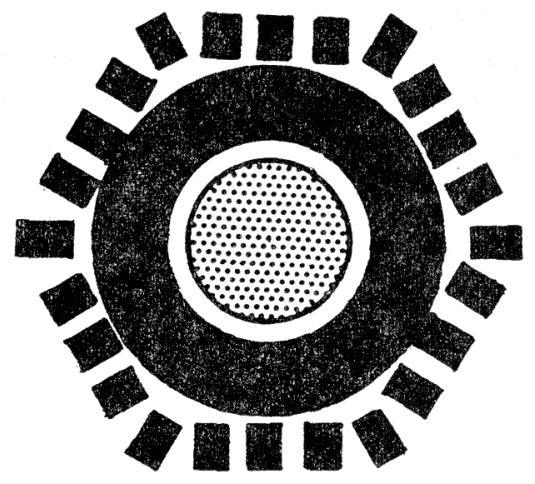

図 3 HVTカプシド断面像の模型図

た．第 3 群は電子密度の高いコアを含をもので，30\%の カプシドがこの群に属し，エンベロープを持った粒子は 通常このコアを有していた。これもやはり円柱状物と円 環体よりなり，第2 群よりも円環体の太さが太い。i から，j とkは横から見たもので岁らう。 FuRLONG ら ${ }^{18)}$ 飞よると，超薄切片のEDTA処理に上り，中心の円柱 状物はタンパク觉，円環体はDNAをそ机艺和含むと述 べている.MDVのDNAの体積は先の分子量から計算 すると1. $17 \times 10^{5} \mathrm{~nm}^{3}$ になる。 しかし第 2 群の円環体の体 積は $4.7 \times 10^{4} \mathrm{~nm}^{3}$ で, も乙第 2 群の円環体をDNA した場合，MDV-DNAの一部しか含み得ないことに なる.第 3 群のコアの体積は $2.0 \times 10^{5} \mathrm{~nm}^{3}$ でDNAの体 積を十分特さめることができる、エンベロープを持った 成熟粒子のコアが第 3 群であったこととも考光合わせ， 第 3 群のコアがその成熟形であることが示唆されだ7).

5） カプシド内でのD NA線維の状態
幸 助

次に円環体のさらに微細な構造を見たいと思い，曆さ $10 \mathrm{~nm}$ の細い円環体を持つコアを選び，写真をずらしな

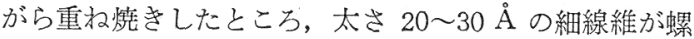
旋状にからまっているように見完た年，それのレザー 光線を用いた光回折装置による回折を行なって見たとこ ろ，4 個の特徵的なスポットが現われ蠌旋を描いている ことが示唆された ${ }^{48)}$.

ところで, MDVのDNAの長さは計測されていない が，計算によると約 $37 \mu \mathrm{m}$ 以上であることがわかる。 これ核ど長い線維が直径わずか $100 \mathrm{~nm}$ のカプシド内に ぞのようにしてつまっているか性生物学上の大きな問題 でも山る. 一つの可能性として, 図 4 の上らに直径 $20 \AA$ のDNA線維（二重螺旋からなる）がへアピン状比れ まがり，それがさらによじれて前述の二重螺旋状を呈 し，タンパク質の円柱の回りを何 10 回も取り巻いて扰 さめられているということが想像された(図 5)。事実核 膜腔内のエンベロープを持っだイルス粒子は一般に dense なコアを持つ之記載されているが32), 注意深く観 察してみると，写真1のように細い円環体と同じょうな 幅の带が多数からみ西っているように見克た ${ }^{47}$.

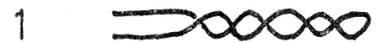

2

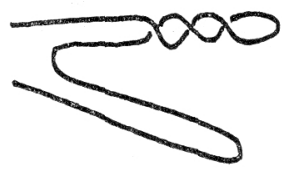

3

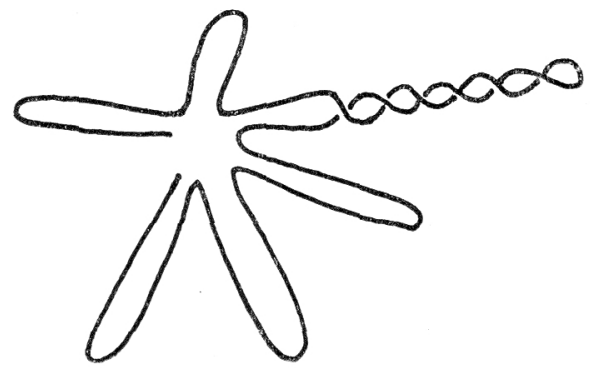

図4ヘルペスウイルスDNA線維の上じれ方の仮説
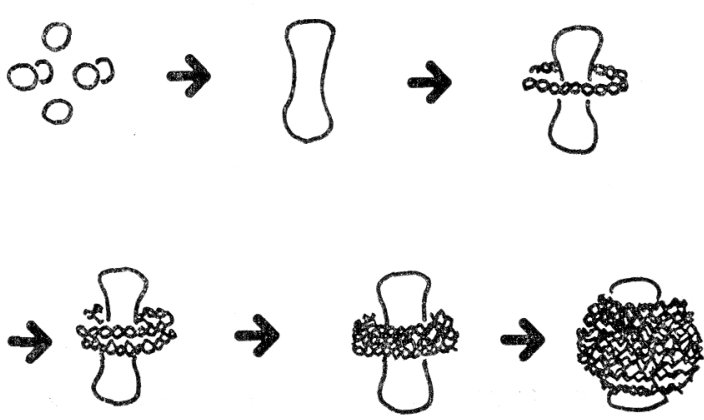

図 $5 \mathrm{MDV}$ 拈よびHVTのコアの形成過程の仮説 


\section{6）小型核内粒子とコアの関係}

小型核内粒子は $\mathrm{MDV}^{7)}, \mathrm{HVT}^{34)}$ 呿よびその他の一 ルペスウイルス 27)で観察されている.いっぽう, 図 2 のb のように中心が十文字に壮たカプシドはHVTで cross-shaped capsid と呼ばれ ${ }^{34)}, \mathrm{MDV}^{46)}$ やその他のへ ルペスウイルス ${ }^{24)}$ でも観察されている. cross-shaped capsid はカプシド内に 6 個の小型核内粒子を入れたもので あることが，コンピューターによる立体再生で確かめら れた ${ }^{2,44)}$.これら小型核内粒子は ${ }^{3} \mathrm{H}$ チミジンでラベルさ

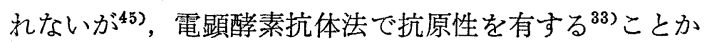
ら一種のタンパク質であると考觉られる.これらは PERDUE $5^{54)}$ がウマのヘルペスウイルスで考觉ているよう に, 特そらく前述のコア内の円柱状物になるのではない かと思われる(図 5).

\section{7）核から細胞質へのカプシドの移動}

次に核内で形成されたカプシドがぞのようにして大型 成熟粒子になるかといら点について述べたい。まず小型 のエンベロープを持った粒子は，多くの他のへルペスウ イルスでも報告されているよう行，核内の未熟粒子が 内側核膜から発芽することによって作られる。ここでい くつかの疑問点にぶつかる. 一つはこの小型のエンベロ 一プを持った粒子は細胞質や細胞外では見られないが， この粒子はぞうなるのであろうか，次に細胞質に多数の 裸のカプシド（未熟粒子）が観察されるが，核内で形成
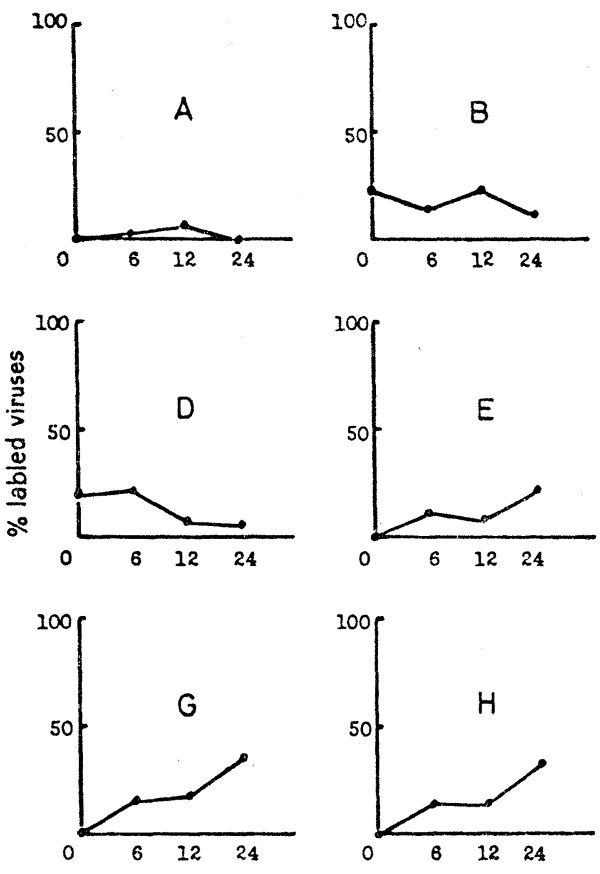

Time after pulse labeling ( $h r)$
されたカプシドがどのようにして細胞質に出現するので あるらか，第 3 に大型成熟粒子とどのような関係がある のか, 等々である.多数の写真を撮影している過程で, こ のエンベロープが再び外側核膜と融合してェンベロープ

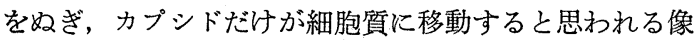
に遭遇した ${ }^{45)}$. このような脱エンベロープについてはカ エルのヘルペスウイルスで報告されている ${ }^{61)}$. も乙脱エ ンベロープが存在するとすると，小型のエンベロープを 持った粒子が細胞質や細胞の外で見られず，また核膜の 崩壊がないのに細胞質にも多数の裸のカプシドが見られ る理由が大変よく理解できる，その他，(1) 核膜孔から 漏れ出るといら考兄や，(2) 核膜の崩壊部から移動する といら説77) も古るが，(1) については穴の直径がウイル スよりやや小さいか同じ程度であり，またその写真を示 した人もない，ただしウイルス感染後期については，核 膜の崩壞が観察される場合もあり，(2) の可能性もある. 脱エンベロープの像がきわめてまれにしか観察されない のは，その過程が極めて短時間に進行するためと考㝋て いる.

\section{8）細胞質におけるエンベロープ獲得様式}

ウイルス感染細胞の細胞質に小胞体に似た扁平囊状の 2 重膜で，囊内にスパイク状の構造が認められる特異な 膜様構造物が認められた (四 7 の F S $)^{45)}$. 筆者ら ${ }^{45}$ はこ れを flasttened sack と呼んだが，細胞質内のカプシドは
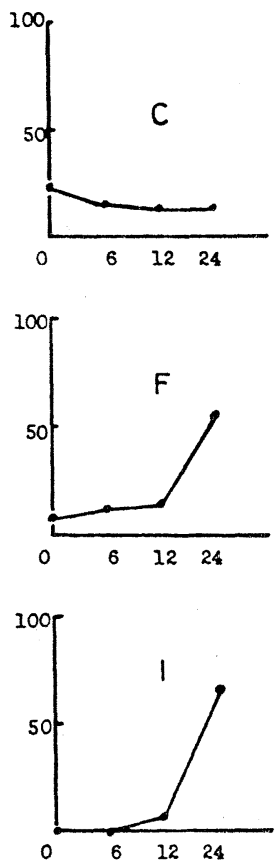

困 $6 \mathrm{HVT}$ 感染細胞の電顕オートラジオグラフィー結果. ${ }^{3} \mathrm{H}$ チミジンで 1 時間パルスラベルした後の各型 ウイルス粒子のラベルされた数（\%) の経時的変化 ${ }^{45)}$ （図 7 の記号扰よび本文参照） 
その部位で電子密度の高い物質とエンベロープを獲得し ていた.この電子密度の高い物質は電顕切片の酵素処理 により一種のタンパク質であるとアヒルのヘルペスウイ ルスで証明されている3).

以上, 電顕写真の形態学的所見から, 感染細胞内での ウイルス発育過程を追うことができたが，実際にウイル スがそのような動きをしているかどうか， ${ }^{3} \mathrm{H}$ チミジン でラベルしたHVTについて電影オートラジオグラフィ ーにより確認した ${ }^{45)}$. 万法としては感染細胞を1時間 ベルした後，アイソトープを含まないCold のチミジン で洗い，6，12，24時間後にそれぞれラベルされたウイ ルスの数を算光た。図 6 の A，B，Cは核内のカプシド であるが，時間とともにラベルされたウイルス粒子が減 少した，核膜腔の小型のエンベロープを持ったウイルス 粒子（D）は 6 時間目が最高で，その後減少している.

それに対し，細胞質内のカプシド（E）や細胞質や細胞 外の大型成熟粒子（F～I ） は時間と共にラベルされた ものが増加し，ウイルスは核から細胞質に移行していく ことが証明されだ5)。

9）細 胞 質 封入体

ヘルペスウイルス感染に和いて，核内封入体のみなら
ず, 細胞質封入体の存在が報告されている ${ }^{30)}$. 筆者らの観 察の結果, 細胞質封入体はカプシドと dense な物質 ${ }^{38)}$ （図７のF）の集ったもの，または限界膜に包まれ大型 成熟粒子がプールされたもの（図 7 の $\mathrm{H}$ ) であり，敊 そらくライソゾームとして運命をたどるものと思われた 45).

\section{0）ウイルスの形態発生まとめ}

図 7 に以上述ベたウイルスの発育過程を模式図にま之 めた。核内で複製されたDNAと細胞質で合成された数 種のウイルスタンパク質は核内でウイルス粒子に合成さ れる. 形態学的にはカプシド内で 6 個の小型核内粒子か ら円柱状物が作られ, その回りをDNA線維が螺旋状に よじれながら何回も取り巻さコアが形成される(図 5 ). でき上がった未熟粒子（コアを含んだカプシド）は内側 核膜で発芽して, 小型のエンベロープを持った粒子(図 7 のD）になる。それらは脱エンベロープするか，または カプシドが核膜の破れ目から出て細胞質に裸のカプシド

（図7のE）が出現する. 次にそれらは flattened sack で dense な物質に包まれ，エンベロープとスパイクを獲 得して大型成熟粒子（図 7 の） になる.

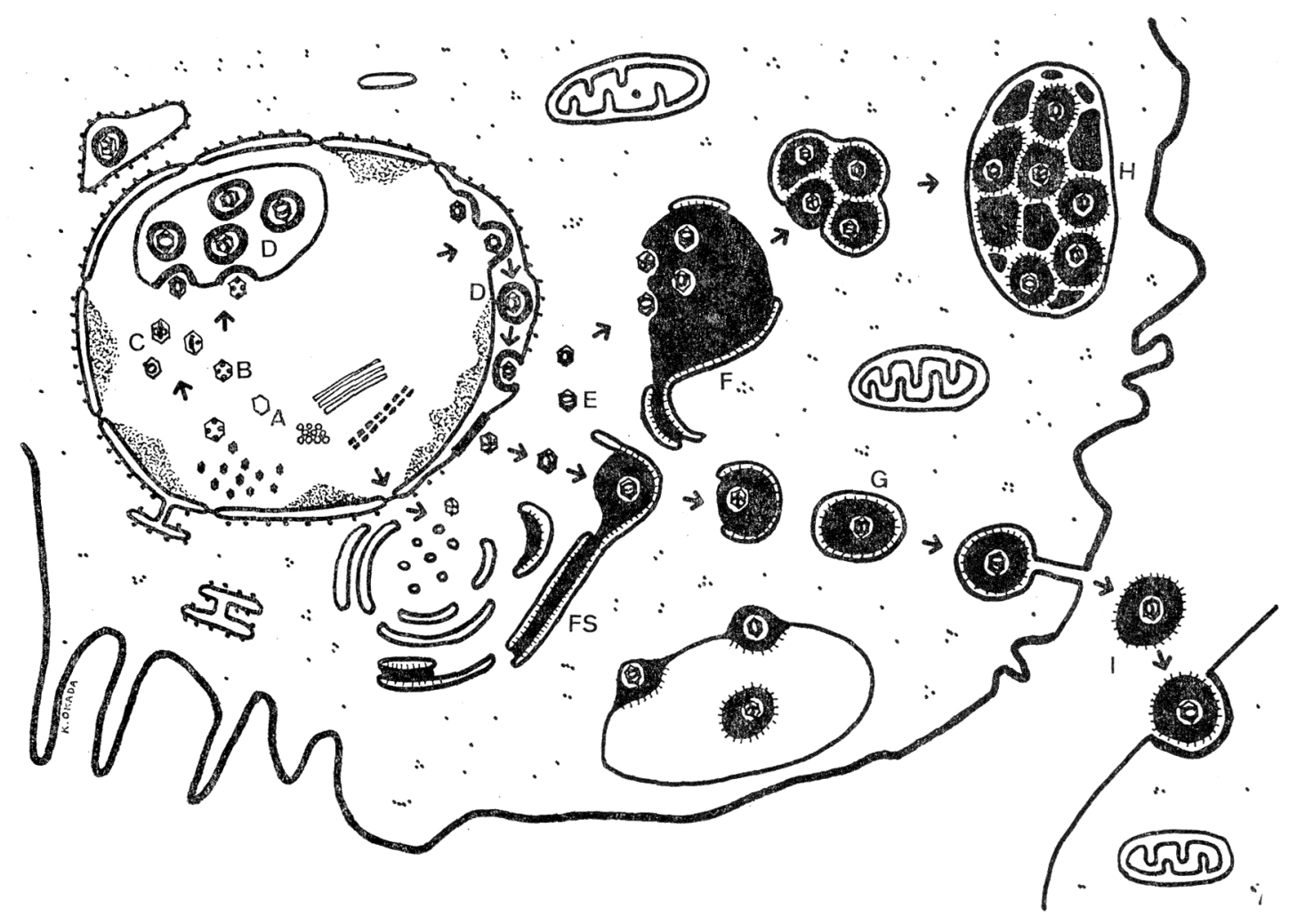

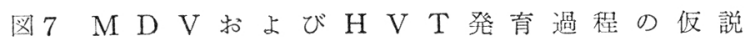




\section{M D の病理発生}

\section{1) 空気伝播}

MDVは著しい細胞結合性を持ら, 細胞が破壊されて ウイルスが細胞から離れると, 感染性は著しくまたは全 く失なわれてしま ${ }^{36)}$. いっぽう, 野外では伝染性が非 常に強く，実験室でも同じ部屋で病鶏と共にヒナを飼育 すると， 2 週間程度のずれで感染と発病が起こる ${ }^{16)}$.ま た,一つの部屋にMDV接種七ナを飼育し,その空気を非 感染ヒナが飼育されている別の部屋にパイプを通して送 ってやると, 発病が起こる ${ }^{8)}$. このことからも空気伝播 が起こることは明らかであるが，これはウイルスの性質 と照らして大きな謎であった. 1969年, ついに感染鷄の 羽包表層上皮に特異螢光抗原が証明され，同部位に核内 封入体が検出された5).さらに細胞質封入体が検出され， 電顕により成熟へルペスウイルスが証明された ${ }^{6,63)}$.こ の部位のウイルスは細胞が死んでもさしつかえないよう な細胞を離れた感染性の大型成熟粒子であっだ). これ らの研究成果によって羽包上皮で增殖したウイルスがフ ケと共に飛散することによって伝播することがわかり， 長年の謎が解決した.

\section{2) 初 期 病 変}

ウイルスは気道感染によりニワトリの体内に侵入す る.ただし感染門戸が上部気道であるのか，肺である か，はたまた気唾であるのかは不明である、 IMAZEKI ${ }^{23)}$ は感染鷄の羽軸をすりつぶし, 粉末とし 4 日踰のヒナに 吸収させたところ，5１0 日目にファブリキウス囊や盲 腸扁桃に著しいリンパ・細網系細胞の過形成を認めた. いっぽう, 移行抗体陰性ヒナの腹腔内にウイルスを接種 した場合には，6〜8日目の脾臓，胸腺，ファブリキウ ス囊に高度のリンパ球の言失と細網細胞ならびに大食細 胞による置換，さらにヘルペスウイルス感染に特徵的な 合胞体形成, 核内・細胞質封入体の形成が認められ, 電 顕によりそこにウイルス粒子が証明された ${ }^{16)}$. FujIмото $ら^{16,19)}$ はこのような病変を「初期変性病変 (initial cytolytic lesion)」と呼んだ.この病変はいったん消失し，接 種後 $2 \sim 3$ 週目になってりンパ腫の形成が認められた 16).すなわち体内に入ったウイルスは, まず脾蔵, 胸 腺, ファブリキウス囊のようなリンパ様器官で増殖し, 標的細胞であるリンパ球に傷害を与え, その後再生する が, 一定期間の後トランスフォーメーションが起こるも のと理解される.な特餘化後胸腺 ${ }^{19}$ やファブリキウス囊 22)を摘出したるのにMDVを接種することにより，初期 変性病変の形成を欠き, このような病変形成に胸腺なら びにファブリキウス囊機能が関与していることを示す成 績を得ている.

\section{3）腫瘍 化（トランスフォーメーション）}

リンパ球には胸腺由来のTリンパ球とファブリキウス
霊由来のB リンパ球があるが，いずれの細胞が腫瘍化し ているのであろらか. (1) 䖝光抗体法で腫瘍細胞を調べ たところ, 大部分が抗 $T$ リンパ球血清と反応し, 少数の 細胞が抗 B リンパ球血清と反応した ${ }^{56)}$. (2) 胸腺または ファブリキウス囊を外科的または化学的に摘除し, それ らのヒナにMDVを接種した場合, 胸腺摘除はリンパ腫 形成を特さえたが59), ファブリキウス慗摘除では変化が なかった 22,60$)$. (3) マレック病のリンパ腫由来長期培養 細胞系にはTリンパ球表面抗原が存在した ${ }^{35)}$. 以上から 腫瘍化している細胞はTリンパ球と思われる。すた直接 証明にはならないが，筆者ら ${ }^{43)} の$ 行なった腫瘍細胞の走 査電顕的観察では概して表面平滑で大型の細胞が大部分 を占め, microvilli の多い細胞は小型で少数であった. 胸腺の細胞は平滑で小型であり，ファブリキウス霊の細 胞は microvilli が多く大型であったことから，大型の平 滑な細胞は腫瘍化したTリンパ球と考えられた。

最近, MURTHY と CALNEK ${ }^{29)}$ はMDVで腫瘍化した 細胞のマーカーともいらべきMAT SA（マレック病関 連表面抗原)を持った細胞が, ウイルス接種後ヒナのどこ に出現するかを䖝光抗体法で調べた. その結果, MATS Aを持った細胞は接種後 5 日目に脾㵴に出現し, 21 日の 実験期間中観察された。次いで 7 日目より低率ではある が, 胸腺, ファブリキウス鼠, 末梢血リンパ球, 骨髄細 胞の間に見られた. ICHJo ら ${ }^{21}$ は脾蔵に打けるリンパ腫 の初期形成部位を検索し, 初めにT-依存域である小動・ ・静脈周团リンパ組織で腫瘍細胞の増殖が起こることを 指摘した. 一つの考えとして脾臓に腫陽化の標的細胞が 多数含まれ, 後にこれらの細胞が全身に移動し, 内蔵諸 臓器や末梢神経に腫瘍を形成するという仮説が成り立 s.

\section{4) 腫瘍細胞の電顕的特徵}

FujrMoTo $5^{12)}$ はMDの病変を腫瘍性增殖性病変のT 型と非腫瘍性反応性病変の $\mathrm{R}$ 型に大別した. $\mathrm{T}$ 型はさら に 3 型に分けられ， T I 型は小型リンパ様細胞から，T II 型は大・中・小リンパ様細胞と細網細胞から， $\mathrm{T}$ II 型は 細網細胞ないし未分化間葉細胞からなる ${ }^{12)}$. 筆者と Fu$\mathrm{JIMOTO}^{42)}$ はこれら病变を特徵づける出現細胞を電顕的に 明らかにした。リンパ様細胞では核ポケットの形成およ び核分裂像が頻発し，未分化なほど核仁が大きく増数 し, 細胞質内のフリーリボゾームが増数し，ロゼット形 成の傾向を示している，したがって，MDはニワトリの 全身のリンパ・細網系の腫瘍性増殖と定義することがで きる12).

いっぽう， R 型は末梢神経に扣いて認められ，小型り ンパ球と形質細胞の浸潤と水腫预よびシュワン細胞の増 殖からなり, 何らかの免疫反応の関与が示唆された

\section{5) 麻痺の発 現機序}

MDは以前, 鶏麻痺 ${ }^{52)}$ や神経型白血病と呼ばれていた 
ほど, 脚や翼の麻㽽は本病の特徵的症状である ${ }^{40)}$. 以前 は簡単に末梢神経に乱ける腫瘍細胞の圧迫で神経変性が 起こり，麻痺をもたらすと考兄られていた ${ }^{52)}$. ところが $\mathrm{R}$ 型のように細胞増殖の少ないものにも麻症は起こる. 古くから一部の研究者の間でMD病変と実験的アレルギ 一性神経炎の類似を指摘するものがあった ${ }^{55)}$. 筆者ら ${ }^{13}$, ${ }^{14,17,20)}$ もとナの実験的アレルギー性神経炎を作り， R 型 病変との類似を報告した. またMD末梢神経の電顕的観 察により, 単核性細胞が有䯣神経の外表をつつむ基底膜 䧶内に侵入し，ミエリン層板をはがし，貧食を行ない， 脱䯣を括こす過程をとら六た ${ }^{15)}$. その他ウオーラー変性 型の軸索と䯣鞘の崩壞やミェリン層板の水腫性変性も見 られたが，主体は実験的アレルギー性神経炎と同じ機転 により脱䯣が起こるものと思われる. へルペスウイルス 感染がどのようにして正常な䯣鞘に対する細胞性免疫反 応，すなおち自己免疫病的な脱䯣をもたらすのであるう か, MD末梢神経のシュワン細胞やリンパ様細胞にウイ ルス粒子を認めたという報告もあるが ${ }^{30)}$, 通常はなかな か認められない、11. しかしMD鷄に末梢神経のミエリン を接種するとアレルギー性皮虐反応が起こったり ${ }^{57)}$, 血 清中に抗神経自己抗体が存在すること年はすで証明さ れている，そこで全くの想像であるが，前述のようにM DVのエンベロープは宿主細胞の細胞膜由来であり, ミ エリンもシュワン細胞の細胞膜であるので, 両者の間に 抗原的な共通性があって, 自己免疫病的脱䯣がもたらさ れるのかむしれない。

\section{6） H V Tワクチン}

HVTがワクチンとしてなぜきくのであろらか, 現在 までのところHVTワクチンの作用機序はまだよく解明 されていない，大きく分けてHVTワクチンの作用機序

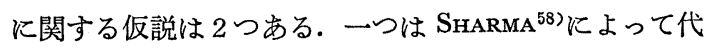
表されるもので, HVTワクチンによって抗MAT S A 細胞性免疫が誘導されMDを防御するというものであ る. 他の一つは PAYNE ら ${ }^{53)}$ による二段階仮説でウイル ス抗原に対して直接, 体液性就よび細胞性免疫が起こ り, 次いで腫瘍細胞に対して直接細胞性免疫が起こると いらものである. もちろん,これらの仮説は相矛盾するも のでなく，両者が実際に働いていることがさまざまな実 験で証明されている.特とらく，(1) 抗体と補体，(2)免疫 Tリンパ球，(3) K細胞（標的細胞飞特異抗体が付着す ると，それを認識し破壊する細胞 : Killer cell), (4)活性 化マクロファージ等がMDV感染細胞膜抗原ないしMA T S Aを標的とするような免疫反応を行ない，腫演の形 成を阻止するのであろ ${ }^{26,62)}$. NUNOYA ${ }^{39}$ はHVT接種 鷄を病理組織学的に観察し, 初期にファブリキウス囊特 よび胸腺に軽度のリンパ様細胞の変性と脾臟における䩗 動脈周团細網細胞の活性化を認めた.ささらにMDVを $\mathrm{H}$ $\mathrm{VT}$ 接種後 4 週目に攻撃したものでは, 初期にリンパ様

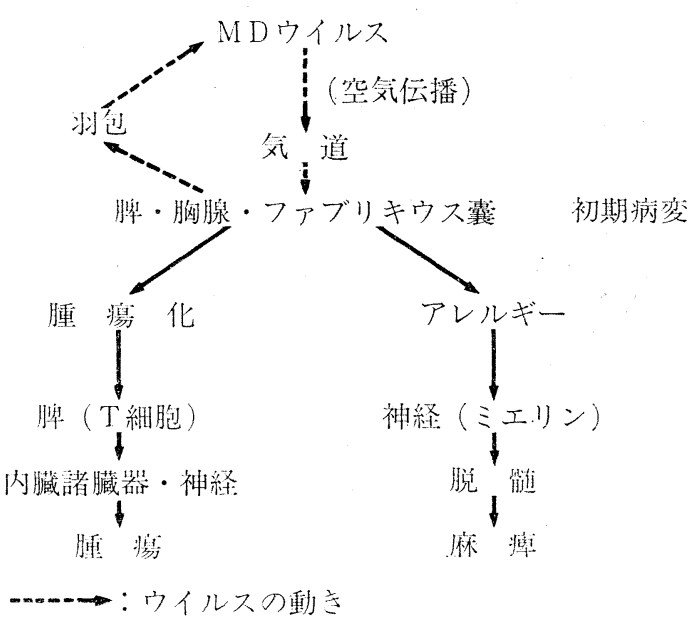

目 $8 \mathrm{M} \quad \mathrm{D}$ の 病理発生

器官の変性脱落と鞘動脈周团に顕著な細網細胞の增殖を 認めた.これらの病理像は上記の仮説を物語っているよ 万㴓われる。

\section{7) M D 病理発生まとめ}

図 8 にMDの病理発生を図式化して示した. 羽根のフ ケに乗ったMDVは気道感染し, 脾臓, 胸腺, ファブリ キウス囊でウイルスは增殖し, 初期病变を形成する. そ の後ウイルス増殖はもっぱら羽包上皮細胞でおこる.い っぽう, 脾㵴等でリンハ球の腫瘍化が抽こり, 次いで全 身の内臓諸臓器や末梢神経にリンパ腫を形成する. 他 方, 自己免疫的機転によりアレルギー性の脱骾が起こ り，麻痺が生じるものと考光る。

以上に述べたMDVの発育過程と病変の形成過程は筆 者の一応の理解であって, ご批判も多いことであろう. また，ワクチンを接種したにるかかわらずMDの発生す る場合があるＨVTワクチンの作用機序を研究するこ とは逆に発癌のメカニズムを明らかにすることになり， この方面の研究が今後に残された問題であるう. 本稿が MDの理解に少しでも役立てば筆者の望外の幸とすると ころである。

稿を終るにあたり，終始あたたかいご指道をいただい $た$, 北海道大学獣医学部の藤本 㭌教授, 見上 彪助教 授ならびに中西 宥助教授につつしんで感謝の意を表す る. 同大学工学部の村田和美教授, 馬場直志博士には画像 解析をしていただき心から感謝申し上げる，実験にご協 カいただいた小沼 操博士，三船喜克技官ならびに比較 病理学教室員各位に和礼申し上げる。また本研究に多大 のご助言をいただいた日本生物科学研究所の田島正典博 士, 北海道大学の梁川 良教授, 岩手大学の大島寛一教 授に感謝申し上げる. 
マレック病および七面鳥へルペスウイルスの構造とをの起病性

\section{主要参考文献}

1) Baba, N., Murata, K., Okada, K., et al.: Optik, 54, $97 \sim 105$ (1979).

2) Baba, N., Murata, K., OKada, K., et al.: Optik, 58, $233 \sim 239$ (1981).

3) Breese, S. S., Dadiri, A. H.: Virology, 34, $160 \sim$ 169 (1968).

4) Calnek, B. W., Adldinger, H. K., Kahn, D. E.: Avian Dis., 14, 219 233 (1970).

5) Calnek, B. W., Hitchner, S. B.: J. Natl. Cancer Inst., 43, 935 949 (1969).

6) Calnek, B. W., Ubertini, T., Adldinger, H. K.: J. Natl. Cancer Inst., 45, $341 \sim 351$ (1970).

7) Churchill, A. E., Biggs, P. M.: Nature (Lond.), 215, $528 \sim 530$ (1967).

8) Colwell, W. M., Schmittle, S. C.: Avian Dis., 12, $724 \sim 729$ (1968).

9) Darlington, R. W., Moss, L. H. III.: J. Virol., 2, $48 \sim 55$ (1968).

10) 藤本 㭌: 獣医畜産新報, (567), 524 530, (568), $581 \sim 589$ (1972).

11) 藤本 㭌: 日獣会誌, $30,558 \sim 560$ (1977).

12) Fujimoto, Y., Nakagawa, M., Okada, K., et al.: Jpn. J. Vet. Res., 19, 7 26 (1971).

13) 藤本 㭌, 岡田幸助：日獣誌, 34 , (学会号), 226 (1972).

14) 藤本 胖, 岡田幸助：日本病理学会会誌, 62, (総 会号), 287 (1973).

15) Fujмото, Y., OKadA, K.: Jpn. J. Vet. Res., 25, $59 \sim 70$ (1977).

16) Fujimoto, Y., Okada, K., Kakihata, K., et al.: Jpn. J. Vet. Res., 22, $80 \sim 93$ (1974).

17) 藤本 㭌, 岡田幸助, 松井高䇠, ほか: 日獣誌, 33, (学会号), 236 (1971).

18) Furlong, D., Swift, H., Roizman, B.: J. Virol., 10, $1071 \sim 1074$ (1972).

19) Goto, N., Fujмото, Y., OKada, K., et all.: Zentralbl. Veterinaermed., B, 26, $61 \sim 72$ (1979).

20) Iсніјо, K., Fujiмото, Y., OкаDA, K.: Zentralbl. Veterinaermed., B, 28, $210 \sim 225$ (1981).

21) Ichijo, K., IsogaI, H., OKada, K., et al.: Zentralbl. Veterinaermed., B, 28, $177 \sim 189$ (1981).

22) IsogaI, H., Fujimoto, Y., OKada, K., et al.: Jpn. J. Vet. Res., 28, $137 \sim 148$ (1980).

23) Imazeki, N.: Jpn. J. Vet. Res., 25, 23 (1977).

24) Johnson, G. R., Koestner, A., Kindig, O., et al.: Pathol. Vet., 6, $289 \sim 308$ (1969).

25) Kawamura, H., King, D. J. Jr., Anderson, D. P.: Avian Dis., 8, $853 \sim 863$ (1969).

26) Kodama, H., Sugimoto, C., Inage, F., et al.: Avian Pathol., 8, 33 44 (1979).

27) Мrуамото, К.: J. Virol., 8, $534 \sim 550$ (1971).

28) 村田和美, 前田純治, 板谷英朗: 北大工学部研究 報告, (74), 53 63 (1974).

29) Murthy, K. K., Calnek, B. W.: J. Natl. Can- cer Inst., 61, 849 854 (1978).

30) Nazerian, K.: J. Natl. Cancer Inst., 47, 207 217 (1971).

31) Nazerian, K.: J. Virol., 13, $1148 \sim 1150$ (1974).

32) Nazerian, K., Burmester, B. R.: Cancer Res., 28, $2454 \sim 2462$ (1968).

33) Nazerian, K., Chen, J. H.: Arch. Gesamte Virusforsch., 41, 59 65 (1973).

34) Nazerian, K., Lee, L. F., Witter, R. L., et al.: Virology, 43, $442 \sim 452$ (1971).

35) Nazerian, K., Sharma, J. M.: J. Natl. Cancer Inst., 54, $277 \sim 279$ (1975).

36) Nazerian, K., Solomon, J. J., Witter, R. L., et al.: Proc. Soc. Exp. Biol. Med., 127, 177 182 (1968).

37) NiI, S.: Biken J., 14, 325 348 (1971).

38) Niı, S., Katsume, I., Ono, K.: Biken J., 16, $111 \sim 116$ (1973).

39) Nunoya, T.: Jpn. J. Vet. Res., 23, $111 \sim 112$ (1975).

40) 岡田幸助: 獣医畜産新報, (469), $435 \sim 442$ (1968).

41) Okada, K., Fujimoto, Y.: Jpn. J. Vet. Res., $18,21 \sim 29$ (1970).

42) Oкаda, K., Fujimoto, Y.: Jpn. J. Vet. Res., 19, $64 \sim 72$ (1971).

43) OKada, K., Fujimoto, Y.: Jpn. J. Vet. Sci., 39, $175 \sim 179$ (1977).

44) Okada, K., Fujimoto, Y., Baba, N.: J. Electronmicrosc., 29, $401 \sim 402$ (1980).

45) Okada, K., Fujimoto, Y., Mikami, T.: Arch. Gesamte Virusforsch., 46, $111 \sim 126$ (1974).

46) Okada, K., Fujimoto, Y., Mikami, T., et al.: Jpn. J. Vet. Res., 20, $57 \sim 68$ (1972).

47) Okada, K., Fujimoto, Y., Nakanishi, Y. H., et al.: Arch. Virol., 59, 137 144 (1979).

48) Okada, K., Fujimoto, Y., Nakanishi, Y. H., et al.: Arch. Virol., 64, $81 \sim 85$ (1980).

49) Okada, K., Fujimoto, Y., Yonehara, K., et al.: J. Electronmicrosc., 23, $133 \sim 135$ (1974).

50) Okazaki, W., Purchase, H. G., Burmester, B. R.: Avian Dis., 14, $413 \sim 429$ (1970).

51）大木与志雄, 武藤正弘, 権 文柱 : 日獣誌, 33, (学会号), 54 (1971).

52) Pappenheimer, A. M., Dunn, L. C., Cone, V.: J. Exp. Med., 49, 63 86 (1929).

53) Payne, L. N., Powell, P. C., Rennie, M. C., et al.: Comp. Immun. Microbiol. infect. Dis., 1, $31 \sim 36$ (1978).

54) Perdue, M. L., Cohen, J. C., Randall, C. C., et al.: Virology, 74, 194 208 (1976).

55) Petek, M., Quagulio, G. L.: Pathol. Vet., 4, $464 \sim 476$ (1967).

56) Rouse, B. T., Wells, R. J. H., Warner, N. L.: J. Immunol., 110, $534 \sim 539$ (1973).

57) Schmahl, W., Hoffmann-Fezer, G., Hoffmann, 


\title{
木原泣陽 木原輝久 梶原富彦 倉内英敏
}

R.: Z. Immunitaetsforsch. Exp. Ther., $150 \mathrm{~S}, 175$ 183 (1975).

58) Sharma, J. M.: In: Avian Immunology, BeneDict, A. A., editor, $345 \sim 353$, New York, Plenum Publishing Co. (1977).

59) Sharma, J. M., Nazerian, K.: J. Natl. Cancer Inst., 58, $689 \sim 692$ (1977).

60) Sharma, J. M., Witter, R. L.: Cancer Res.,
$35,711 \sim 717$ (1975).

61) Stackpole, C. W.: J. Virol., 4, 75 93 (1969).

62) Sugrmoto, C., Kodama, H., Mikami, T.: Jpn. J. Vet. Res., 26, $57 \sim 67$ (1978).

63) 田島正典, 板橋正文, 木谷真三 : 日獣会誌, 26 , $128 \sim 133$ (1973).

64) Witter, R. L., Nazerian, K., Purchase, H. G., et al.: Am. J. Vet. Res., 31, 525 538 (1970).

\section{犬に対する犬糸状虫子宮内虫卵の静脈内注射の影響}

\author{
木原滋陽*1） 木原輝久*2）梶原富彦*3) 倉内英敏*4)
}

（昭和 56 年 5 月 22 日受理）

Influence of Intrauterine Dirofilaria Eggs Injected Intravenously into Dogs

Shigeharu Kihara (Practitioner in Beppu, Oita 874) et al.

\section{SUMMARY}

Seven dogs free from Dirofilaria immitis (group 1) and 5 dogs infected with this parasite (group 2) were injected intravenously with such amount of eggs as contained in the uterus of one worm of this parasite or onehalf of this amount per $\mathrm{kg}$ of body weight. These eggs had been suspended in physiological saline. All the dogs manifested severe symptoms immediately after injection. Finally, 2 dogs of group 1 and 3 dogs of group 2 died within 3 hours after injection. One dog of this group succumbed 4 days after injection.

Chest X-ray examination revealed homogeneous shadows on the dorsal side. This finding was more conspicuous in group 2 than in group 1 . There were many eggs blocking capillaries in the lung.

\section{要約}

犬糸状虫の外科的摘出, とくに頸静脈からの摘出に際して虫体が倠つくことが少なくない。もし雌虫体が 傷つけば子宮内容の虫卵が血液に流入する，この虫卵流入による影響を知るために実験を行なった．今回は 卵子流入による症状, 転帰, 胸部X線像の変化, 肺毛細血管栓塞の有無について調べた. 体重 $\mathrm{kg}$ 当たり 0.5 隻と 1 隻分の子宮内虫畉の生理食塩液浮遊液を犬系状虫非寄生犬 7 頭, 寄生犬 5 頭に静注した. 虫卵注 入後ただちに重篤な症状を呈し，非寄生犬では 2 頭，寄生犬では 3 頭が 3 時間以内に死亡した（寄生犬の 1 頭は 3 日間観察後死亡). 胸部X線像では肺の, とくに背側に均質的な陰影がみられ, 变化は犬系状虫寄生犬 のほうが強かった．肺の組織像では，毛細血管に栓塞した虫卵が多数みられた．

犬系状虫は硬い器具による圧迫, とくに光の尖ったようなものによる僅かな穿刺や, 虫体が異常に捱られ ることなどによって容易に傷つき，内容が逸出する，犬糸状虫の摘出時に死の転帰をとり，剖検に和いても 死因が㨔及難い例は, 本実験成績から, 虫体破損に上る虫卵などの流入によることが考㝋られる. 犬系状虫 の外科的摘出が多く行なわれている現在, 虫体破損による障害を考古必要がある.

犬系状虫症については多くの研究がなされている.成 虫の駆除には旧くから薬剂による駆虫が行なわれてきた が, 近年, 外科的な虫体の摘出, すなわち右心室, 右心 房, 肺動脈からの摘出法が開発され, 最近の Vena Cava

\footnotetext{
* 大分県 開業 $(1,3,4)$ 大分県別府市京町 3-27

2) 大分県別府市荘園 6 組)
}

Syndrome の解明とともに頸静脈からの吊出しが広く一 般的に行なわれるようになった。この摘出に際して，予 想外の死の転帰をとり，剖検によっても原因不明な例が 劣る. その原因究明の一環として摘出時の破損虫体の内 容物が血液に流入した場合の影響について実験を行なっ た.とくに雌の虫体が傷つけば，体腔のほとんど全容積

日獣会誌 $34 \quad 471 \sim 477 \quad$ (1981) 